\title{
Is metal disposal toxic to deep oceans?
}

\author{
E. G. Nisbet and C. M. R. Fowler
}

THE controversy over the proposal by the Shell Oil Company to sink the Brent Spar oil storage platform in the North Atlantic - and the company's decision to abandon this plan under pressure from the environmentalist group Greenpeace - centres on the question of the toxicity of metals in the tanks and ballast of the platform.

The metals involved are said to include "hundreds of kilograms" of cadmium, mercury, zinc, lead and nickel, as well as varying amounts of aluminium, copper, radioactive material and steel, 40 tonnes of oil and 100 tonnes of silt ${ }^{1}$.

To put these quantities in context, estimates of metals released by natural systems in the Broken Spur hydrothermal vent field in the North Atlantic range from 500,000 to 5 million tonnes a year ${ }^{2}$. In other words, a single vent field can emit annually orders of magnitude more of each heavy metal than is contained in the Brent Spar.

Ocean-floor sediment lying on new mid-ocean crust can be extremely rich in metals. For example, in the NESCA area in the northeast Pacific, a small area measuring 600 metres by 1,200 metres was found to contain 1-1.5 tonnes of uranium within its top metre of sediment, as well as about 4,000 tonnes of magnesium. Elements enriched in the sediments also included iron, manganese, aluminium, silver, barium, chromium, copper, lithium, nickel, lead, strontium, vanadium, zinc and rare-earths ${ }^{3}$.

Cadmium is another element characteristically enriched in sediments at midocean ridges, and found for instance on the Gorda Ridge ${ }^{4}$ in the Pacific, and around the TAG hydrothermal mound in the North Atlantic. Locally, surface sediment is $20-40$ per cent iron'.

A thriving biological community exists around many metal-rich deposits, and for some ecosystems around mid-ocean ridges a supply of heavy metals is essential. Bacterial mats on polymetal sulphide surfaces appear to use as their chemolithotrophic electron or energy sources either dissolved minerals or solid metal sulphides ${ }^{6}$.

The hydrothermal supply may ultimately introduce into the oceans some of the iron, manganese and sulphur that are essential to planktonic photosynthesis, as well as metals for important metalloproteins in marine life, such as nickel in urease, and zinc, copper, cobalt, molybdenum, mercury and cadmium in various planktonic proteins.

Finally, oils are produced by some sediment-covered systems, for example in the Guaymas Basin in the Gulf of California.
Here, in addition to metals such as iron, lead, zinc, copper, arsenic, cadmium, manganese and antimony $^{7}$, a condensate contains $\mathrm{C}_{1}-\mathrm{C}_{20}$ hydrocarbons and polynuclear aromatic hydrocarbons such as phenanthrene, anthracene, fluoranthene, pyrene, benzanthracene, chrysene, and benzofluoranthene ${ }^{8}$, made in situ by ridge processes.

The ocean floor is diverse, and we can distinguish between shallow seas, deep ocean floor and nearridge settings. In shallow seas, the contents of the Brent Spar would indeed probably damage local marine life. In contrast, in the special environment around mid-oceanridge hydrothermal systems, the arrival of the metals of the Brent Spar would not be out of the ordinary, and indeed might even be beneficial as a mimic of vent activity.

The amounts of metals on the Brent Spar would be small here compared to local geological sources of elements, from magnesium to uranium, and local sediment would typically be metalliferous. As a result, the addition of extra dumped metals would probably act as nutrient to the local ecosystem.

In deeper seas, where the planned disposal of the Brent Spar was to have occurred, localized off-ridge venting occurs, and locally bottom conditions may occasionally be metal rich. As a result, the environmental damage from the disposal of the Brent Spar in this setting would probably be minimal.

The alternative to dumping on the deep ocean floor is to dispose of the heavy metals from the Brent Spar on land. But this will be problematic, as it will involve a difficult breaking-up process, followed by storage in a landfill, where aquifers may become contaminated. To land biota, elements such as cadmium can be very toxic.

We should be cautious of excessively anthropomorphic thinking; one man's poison is a bacterium's meat. A suitable disposal site could be in a carefully chosen location on the Mid-Atlantic Ridge, where the materials of Brent Spar would not necessarily be toxic to the local ecology.

Ironically, the recent G7 meeting of world leaders, at which the Brent Spar was discussed, took place within sight of one of the world's great marine research institutions, the Bedford Institute of Oceanography in Dartmouth, Nova Scotia. Had advice of scientists at the institute been asked for at the meeting, the Brent

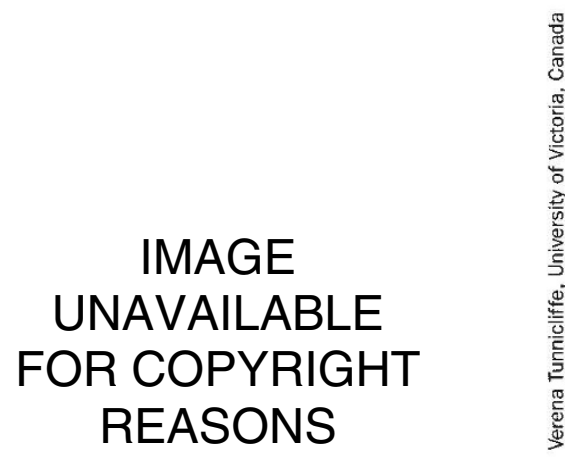

Life and depth: A black smoker in the hydrothermal vent field on the Juan de Fuca Ridge (northeast Pacific) at a depth of 2,200 metres. The emerging fluid is at over $350^{\circ} \mathrm{C}$, and 'smoke' is formed when contact with surrounding cold seawater causes metal sulphides to precipitate. Vent animals adapted to these conditions, such as white vestimentiferan tubeworms, grey limpets and several polychaete worm species, live in a steep temperature gradient within centimetres of this fluid. Tentacles at upper right belong to alvinellid polychaetes, which build tubes of metal sulphide particles and have high concentrations of elements such as cadmium, mercury and uranium in their secreted mucus $^{9}$. The view illustrated is about three metres width.

Spar affair might have been dealt with very differently and attention could have been focused on more important issues.

Arguably the most pressing environmental problem is overfishing in the North Atlantic, which urgently needs the wise political leadership that could have emerged from the Halifax meeting. By concentrating on and sensationalizing relatively small problems, we risk making poor judgements and neglecting more serious issues facing the environment.

E. G. Nisbet and C. M. R. Fowler are at Royal Holloway, University of London, Egham, Surrey TW2O OEX, UK.

1. Linklater, M. The Times 20 June 1995

2. Nesbitt, R. W. \& Murton, B. J. BRIDGE Newsl. 8, 35-37 (1995).

3. German, C. R. et al. Chem. Geol. 119, 175-190 (1995)

4. Koski, R. A. et al. Can. Mineralogist 26, 655-673 (1988).

5. German, C. R. et al. J. geophys. Res. 98, 9683-9692 (1993).

6. Wirsen, C. O. et al. J. geophys. Res. 98, 9692-9703 (1993)

. Peter, J. M. \& Scott, S. D. Can. Mineralogist 26, 567-588 (1988).

8. Gieskes, J. M. et al. Can. Mineralogist 26, 589-602 (1988).

9. Juniper, S. K. et al. Deep Sea Res. 33, 339-347 (1986). 